\title{
Beleidsregel Dinas Perdagangan dan Perindustrian dalam Mengoptimalkan Pasar Rakyat Tualang Tahun 2018
}

\section{Beleidsregel Department of Trade and Industry in Optimizing the Tualang People's Market in 2018}

\author{
Wulan Dari \& Adlin* \\ Jurusan Ilmu Pemerintahan, Universitas Riau, Indonesia \\ Diterima: 05 Juni 2021 Direview: 05 Juni 2021; Disetujui: 14 Agustus 2021 \\ *Corresponding E-mail : adlin@lecturer.unri.ac.id
}

\begin{abstract}
Abstrak
Penulisan artikel ilmiah ini mengangkat fenomena yang terjadi di dalam masyarakat Kecamatan Tualang pada proses penegakan Surat Edaran No. 511.2/DPP/PSR/IX/2018/200 dalam merelokasi pedagang kaki lima dari pinggir dan bahu jalan raya KM 4 depan Pasar Tuah Serumpun ke Pasar Rakyat Tualang tahun 2018. Permasalahan ini dapat dianalisis dengan menggunakan teori persyaratan yang harus dipenuhi dalam pembuatan beleidsregel Van Kreveld (dikutip oleh Indroharto dalam Ridwan HR, 2007) dan penerapan/penegakan beleidsregels Ridwan HR (2007) serta dengan menggunakan teori faktorfaktor yang mempengaruhi penegakan hukum Soerjono Soekanto (2008). Hasil dari artikel ilmiah ini menunjukan bahwa Surat Edaran No. 511.2/DPP/PSR/IX/2018/200 sudah memenuhi persyaratan yang harus dipenuhi dalam pembuatan beleidsregels. Akan tetapi dari segi penerapan, surat edaran tersebut belum sepenuhnya memenuhi syarat yang diperlukan. Adapun faktor-faktor yang menghambat penegakan surat edaran diantaranya faktor penegak hukum, faktor sarana dan fasilitas, faktor masyarakat dan faktor kebudayaan. Sementara faktor hukum tidak menjadi penghambat penegakan surat edaran.
\end{abstract}

Kata Kunci: Beleidsregel; Pasar Rakyat; Pedagang Kaki Lima

\begin{abstract}
The writing of this scientific article raises the phenomenon that occurs in the Tualang District community in the process of enforcing Circular No. 511.2/DPP/PSR/IX/2018/200 in relocating street vendors from the edge and shoulder of the KM 4 highway in front of Tuah Serumpun Market to Tualang People's Market in 2018. This problem can be analyzed using the theory of requirements that must be met in the manufacture of beleidsregel Van Kreveld (quoted by Indroharto in Ridwan HR, 2007) and the application/enforcement of the regulations of Ridwan HR (2007) as well as by using the theory of factors influencing law enforcement Soerjono Soekanto (2008). The results of this scientific article show that Circular No. 511.2/DPP/PSR/IX/2018/200 has met the requirements that must be met in the manufacture of beleidsregels. However, in terms of implementation, the circular has not fully met the required requirements. The factors that hinder the enforcement of circulars include law enforcement factors, facilities and facilities factors, community factors, and cultural factors. Meanwhile, legal factors do not hinder the enforcement of the circular.
\end{abstract}

Keywords: Beleidsregel; People's Market; Street Vendors

How to Cite: Dari, W. \& Adlin. (2021). Beleidsregel Dinas Perdagangan dan Perindustrian dalam Mengoptimalkan Pasar Rakyat Tualang Tahun 2018, Journal of Education, Humaniora and Social Sciences (JEHSS). 4 (2): 923-930. 


\section{PENDAHULUAN}

Pasar tradisional atau pasar rakyat dalam Undang Undang Nomor 7 Tahun 2014 yang merupakan salah satu contoh kebutuhan masyarakat yang dari dulu hingga saat ini masih tetap eksis keberadaannya meskipun kini telah memiliki pesaing yang lebih unggul yakni pasar modern (Undang Undang Republik Indonesia, 2014b).

Sejak diberlakukannya Undang-Undang Nomor 22 Tahun 1999 yang kemudian diubah dengan Undang-Undang Nomor 32 Tahun 2004 dan diubah kembali dengan Undang-Undang Nomor 23 Tahun 2014 tentang Pemerintahan Daerah, otonomi daerah terus bergulir dijalankan yang ditandai dengan adanya desentralisasi beberapa kewenangan pemerintah kepada daerah melalui urusan pemerintahan konkuren. Dalam pasal 12 ayat 2 (point k) dan ayat 3 (point f) disebutkan bahwa yang menjadi urusan pemerintah daerah adalah terkait pengelolaan koperasi, usaha kecil dan menengah, serta perdagangan termasuk pengelolaan pasar tradisional sebagai area berdagang. Selain itu, daerah juga dapat melaksanakan sebagian urusan pemerintah pusat yang ditugaskan langsung pemerintah pusat melalui asas tugas pembantuan. Adanya otonomi daerah ini, diharapkan daerah kuat sehingga berdampak positif terhadap kuatnya negara, karena daerah adalah pilar bagi sebuah negara (Syaukani et al., 2009);(Undang Undang Republik Indonesia, 1999);(Undang Undang Republik Indonesia, 2004);(Undang Undang Republik Indonesia, 2014a).

Kabupaten Siak sebagai salah satu daerah otonom yang berada di wilayah Provinsi Riau terus melakukan kewajibannya dalam menyelenggarakan pemerintahan daerah demi meningkatkan kesejahteraan, kemakmuran, keamanan dan ketertiban masyarakat Kabupaten Siak dalam berbagai bidang. Salah satu upaya yang dilakukan pemerintah Kabupaten Siak dalam meningkatkan kesejahteraan dan ketertiban di masyarakat adalah dengan melakukan pembangunan gedung pasar tradisional yang layak pakai dengan tujuan agar pendapatan masyarakat semakin meningkat, penataan pasar menjadi lebih rapi dan sehat, penataan tata lahan kota menjadi lebih indah serta agar para pedagang dan masyarakat menjadi lebih tertib. Hingga tahun 2018, jumlah pasar tradisional yang terdapat di Kabupaten Siak sebanyak 16 pasar. Berikut tabel jumlah pasar rakyat di Kabupaten Siak :

Tabel 1. Jumlah Pasar Tradisional di Kabupaten Siak

\begin{tabular}{clll}
\hline No. & \multicolumn{1}{c}{ Nama Pasar Tradisional } & \multicolumn{1}{c}{ Sumber Biaya } & \multicolumn{1}{c}{ Kecamatan } \\
\hline 1. & Pasar Rakyat Tualang & Dana Tugas Pembantuan & Tualang \\
2. & Pasar Tuah Serumpun & DAK & Tualang \\
3. & Pasar Bunut & DAK & Tualang \\
4. & Pasar Belantik & APBD & Siak \\
5. & Pasar Tuah Sekato & APBD & Mempura \\
6. & Pasar Bunga Raya & APBD & Bunga Raya \\
7. & Pasar Dayun & APBD & Dayun \\
8. & Pasar Sungai Mandau & DAK & Sungai Mandau \\
9. & Pasar Kerinci Kanan & DAK & Kerinci Kanan \\
10. & Pasar Gasip & DAK & Koto Gasip \\
11. & Pasar Minggu Kandis & APBD & Kandis \\
12. & Pasar Minas & APBD & Minas \\
13. & Pasar Datuk Sabandar & DAK & Sabak Auh \\
14. & Pasar Dosan & APBD & Pusako \\
15. & Pasar Pekan Raya & APBD & Sungai Apit \\
16. & Pasar Rindu Alam & APBD & Kandis \\
\hline
\end{tabular}

Sumber : Korwil III Pengelolaan Pasar kec Tualang dan Sungai Mandau Tahun 2017 dan KASI Operasional Pasar dan Retribusi Pasar Dinas Perdagangan dan Perindustrian Kab Siak yang diolah kembali oleh penulis, 2019.

Kecamatan Tualang merupakan kecamatan yang memiliki jumlah penduduk terbanyak di Kabupaten Siak sebanyak penduduk 112.901 jiwa(Badan Pusat Statistik kabupaten Siak, 2019). Dengan potensi jumlah penduduk yang banyak tersebut, keberadaan akan pasar tradisional 
menjadi hal yang penting, mengingat harga yang ditawarkan pada pasar tradisional lebih murah dan dapat ditawar meskipun keadaan lingkungan pasar tradisional tidak senyaman dan sebersih pasar modern.

Pasar Tuah Serumpun merupakan pasar tradisional yang paling padat jumlah pedagangnya sehingga, ketidakcukupan tempat yang tersedia di Pasar Tuah Serumpun menimbulkan masalah pada tempat berjualan bagi pedagang kaki lima. Jumlah pedagang kaki lima yang berjualan di sepanjang Jalan Raya KM 4 depan Pasar Tuah Serumpun mencapa 120 pedagang. Untuk mengatasi permasalahan tersebut, maka Pemerintah Kabupaten Siak melakukan upaya dan langkah nyata dengan membangun Pasar Rakyat Tualang sesuai dengan perintah Permendag No. 34/MDAG/PER/5/2017 tentang Perubahan atas Permendag RI No. 15/M-DAG/PER/2/2017 tentang Penugasan Gubernur, Bupati/Walikota dalam Rangka Pelaksanaan Kegiatan Pembangunan/Revitalisasi Sarana Perdagangan yang Didanai dengan Dana Tugas Pembantuan APBN Tahun Anggaran 2017.

Pasar Rakyat Tualang merupakan pasar pemerintah yang diresmikan pada 7 Februari 2018 oleh Bupati Siak, Syamsuar. Pasar Rakyat Tualang terletak di Jalan Raya KM 7 Perawang berlokasi di area bekas terminal lama Perawang. Pasar yang menghabiskan dana APBN 2017 sebesar Rp 5.441.935.000 melalui Dana Tugas Pembantuan ini adalah pasar tradisional tipe B yang memiliki luas lahan $\pm 1500 \mathrm{~m}^{2}$ dengan 198 unit los terdiri dari 160 los basah, dan 38 los kering berukuran $2 \times 1,5 \mathrm{~m}$ dan 35 unit kios berukuran $3 \times 2 \mathrm{~m}$ dengan kapasitas minimal 70 pedagang ( hasil wawancara dengan Kepala Bidang Perdagangan Dinas perdagangan dan perindustrian Kabupaten Siak, 8 April 2019).

Upaya tindak lanjut dari kebijakan pembangunan tersebut, dilakukannya sosialisasi Pasar Rakyat Tualang yang bersimultan dengan diedarkannya Surat Edaran Dinas Perdagangan dan Perindustrian Kabupaten Siak No. 511.2/DPP/PSR/IX/2018/200 yang berisi himbauan dan perintah untuk pindah dari lokasi berdagang lama ke lokasi berdagang yang baru (Pasar Rakyat Tualang) sebelum tanggal 25 September 2018. Surat edaran seringsekali bermasalah dalam implementasinya di lapangan karena kurang dipatuhi oleh masyarakat (Adlin \& Yusri, 2020).

Pasca surat edaran diedarkan, jumlah pedagang kaki lima yang berminat untuk pindah ke Pasar Rakyat Tualang mencapai 120 orang. Akan tetapi, kurang dari satu bulan sejak diresmikan Bupati Siak, pasar baru tersebut tidak beroperasi lagi yang disebabkan karena yang pertama, pemindahan para pedagang Pasar Tuah Serumpun dilakukan secara tidak serentak dan kedua area pasar terlalu sempit dan pengap. Alhasil, sejak dikeluarkan SK Hibah : Berita Acara Serah Terima No. 97/M-DAG/BAST/10/2018 pada tahun 2019 Pasar Rakyat Tualang tidak termanfaatkan secara optimal untuk kegiatan berdagang. Hal ini menunjukan masyarakat kurang patuh pada kebijakan yang telah dibuat pemerintah daerah. partisipasi seseorang bisa jadi berkaitan dengan perhitungan untung rugi akibat dampak kegiatan yang akan dilakukan, jika cenderung merugikan atau dinilai tidak bermanfaat menurut subjetifitas pelaku maka kegiatan tersebut tidak akan dilakukan (Adlin \& Siregar, 2021).

Penelitian mengenai relokasi pedagang kaki lima maupun mengenai penataan pasar tradisional telah banyak dilakukan oleh peneliti-peneliti terdahulu. Muhammad Faundra (2016) dengan judul 'Relokasi Pasar Puakang ke Pasar Puan Maimun di Kabupaten Karimun Tahun 20122013' menjelaskan bahwa pelakanaan kebijakan relokasi Pasar Puakang tidak berjalan baik, hal tersebut dapat terlihat dari kecakapan pelaksana tidak cukup baik tanpa kesediaan dan komitmen untuk melaksanakan kebijakan selain itu sarana dan prasarana yang disediakan Dinas Koperasi, UKM, Perindustrian dan Perdagangan juga tidak mencukupi (Faundra, 2016). Kemudian hasil penelitian dari Bastian (2018) yang berjudul Upaya 'Penataan Pasar Pajak Lama oleh Pemerintah Daerah Kabupaten Rokan Hilir Tahun 2017' yang menjelaskan bahwa upaya penataan Pasar Pajak Lama oleh Pemerintah Daerah Kabupaten Rokan Hilir belum maksimal, baik dari segi RTRW yang ada di Kabupaten Rohil yang belum rampung, selain itu proker dari Disperindag dan Pasar pada tahun 2017 tidak ada tentang penataan pasar. Kendala dalam upaya penataan adalah kesadaran dari para pedagang untuk tidak berjualan di sembarangan tempat dan kurangnya sarana parasarana seperti mobil operasional dan dana operasional (Sebastian, 2018). Perbedaan 
penelitian ini dengan penelitian terdahulu adalah jika penelitian terdahulu lebih menekankan terhadap kebijakan dan pengambilan keputusan dalam merelokasi pedagang dan pengelolaan pasar pengelolaan pasar, sementara penelitian penulis lebih melihat tindakan hukum publik pemerintah melalui instrumen tindakan pemerintah beleidsregels dalam hal ini surat edaran dalam mengoptimalkan pasar tradisional melalui relokasi pedagang kaki lima.

Berdasarkan permasalahan yang telah dipaparkan di atas, dapat diketahui bahwa tidak adanya kepatuhan dari pedagang kaki lima terhadap surat edaran Dinas Perdagangan dan Perindustrian Kabupaten Siak. Oleh karena itu, tulisan ini melakukan analisis penerapan surat edaran dan berupaya menggambarkan faktor yang mempengaruhi belum efektifnya penerapan surat edaran guna mengoptimalkan Pasar Rakyat Tualang tahun 2018.

\section{METODE PENELITIAN}

Penelitian ini menggunakan pendekatan kualitatif. Disebut metode kualitatif karena data penelitian berupa data kualitatif yang diungkapkan dalam bentuk kalimat serta uraian-uraian bahkan dapat berupa cerita pendek(Bungin, 2013). Data kualitatif bersifat subjektif, sehingga peneliti yang menggunakan data penelitian kualitatif harus sedapat mungkin untuk menghindari sikap subjektif yang dapat mengaburkan objektivitas data penelitian. Adapun jenis penelitian adalah deskriptif yang bertujuan untuk membuat gambaran secara sistematis, faktual dan akurat mengenai fakta -fakta dan sifat -sifat pada suatu obyek penelitian tertentu dengan menggunakan metode kualitatif. pengumpulan data dilakukan melalui observasi, wawancara dan penelusuran dokumen. Informan penelitian sebanyak 12 orang terdiri dari unsur dinas perdagangan kabupaten siak, anggota DPRD Kabupaten Siak, Pegawai Penyidik PNS kabuapten Siak, Akademisi hukum Tata Negara, Pedagang di Pasar Tualang dan masyarakat yang biasa datang ke pasar Tualang. Analisa data dilakukan analisis interaktif yang dikemukakan Miles dan Huberman di mulai dari pengumpulan data, reduksi data, display data dan penarikan kesimpulan.

\section{HASIL DAN PEMBAHASAN \\ Pembuatan Beleidsregel oleh Dinas Perdagangan dan Perindustrian dalam mengoptimalkan Pasar Rakyat Tualang di Kecamatan Tualang Kabupaten Siak Tahun 2018}

Beleidsregels atau peraturan kebijakan merupakan instrumen yang sering digunakan pemerintah dalam penyelenggaraan pemerintahan sehari-hari serta pembentukannya pun merupakan hal yang lumrah terjadi. Beleidsregels meliputi peraturan, pedoman, pengumuman serta surat edaran (Ilmar, 2014). Pembuatan Beleidsregel dikaitkan permasalahan masyarakat yang terus berkembang sehingga menuntut pemerintah membuat kebijakan yang cepat untuk menyelesaikan masalah yang sedang dihadapi (Eric \& Anggraita, 2021);(Yuliansyah, 2015);(Anam \& Hafiz, 2015). Dalam bahasa lain beliedsragel diperlukan menutup kekosongan hukum guna menyelesaikan permasalahan baru yang muncul di masyarakat(Ismahyuni, 2018). Van Kreveld yang dikutip oleh Indroharto, mengemukakan bahwa pembuatan beleidsregel juga harus memenuhi syarat-syarat tertentu untuk kemudian dapat berlaku yaitu (Ridwan, 2007): 1) Beleidsregels tidak boleh bertentangan dengan peraturan dasar yang mengandung wewenang diskresioner yang dijabarkannya 2) Beleidsregels tidak dapat bertentangan dengan nalar sehat; 3) Beleidsregels harus dipersiapkan dengan cermat; 4) Isi beleidsregels atau peraturan kebijakan harus jelas memuat hak dan kewajiban warga masyarakat yang terkena peraturan tersebut dan ada kepastian hukum formal; 5) Pertimbangan beleidsregels tidak harus rinci, tetapi tujuan dan dasar pertimbangan mengenai kebijaksanaan yang akan ditempuh harus jelas; 6) Beleidsregels harus memenuhi syarat kepastian hukum materiil, artinya hak yang telah diperoleh dari warga negara yang terkena kebijaksanaan tersebut harus dihormati, kemudian harapan-harapan yang telah ditimbulkan jangan sampai diingkari.

Berdasarkan indikator yang dikemukukanan Kreveld, dilakukan penilaian terhadap Surat Edaran No. 511.2/DPP/PSR/IX/2018/200 yang dibuat oleh Dinas Perdagangan dan Perindustrian Kabupaten Siak. Berdasarkan hasil wawancara dengan para informan, berikut tabel penilaian Surat Edaran No.511.2/DPP/PSR/IX/2018/200. 
Tabel 3. Penilaian Surat Edaran No. 511.2/DPP/PSR/IX/2018/20o berdasarkan persyaratan pembuatannya

\begin{tabular}{|c|c|c|}
\hline No. & Persyaratan dalam Pembuatan Beleidsregel & Keterangan \\
\hline 1. & $\begin{array}{l}\text { Tidak boleh bertentangan dengan peraturan dasar } \\
\text { yang mengandung wewenang diskresioner yang } \\
\text { dijabarkannya }\end{array}$ & Tidak bertentangan \\
\hline 2. & Tidak dapat bertentang dengan nalar sehat & Tidak bertentangan \\
\hline 3. & Dipersiapkan dengan cermat & Dengan cermat \\
\hline 4. & $\begin{array}{l}\text { Memuat hak dan kewajiban warga masyarakat yang } \\
\text { terkena peraturan tersebut dan ada kepastian } \\
\text { hukum formal. }\end{array}$ & Memuat \\
\hline 5 & $\begin{array}{l}\text { Tujuan dan dasar pertimbangan mengenai } \\
\text { kebijaksanaan yang akan ditempuh harus jelas. }\end{array}$ & $\begin{array}{l}\text { Tujuan dan pertimbangan } \\
\text { jelas }\end{array}$ \\
\hline 6. & Memenuhi syarat kepastian hukum materiil & $\begin{array}{l}\text { Memuhi syarat kepastian } \\
\text { hukum materiil }\end{array}$ \\
\hline
\end{tabular}

Sumber : Hasil wawancara dengan para Informan dan Olahan Penulis, 2019.

Berdasarkan enam persyaratan yang harus dipenuhi dalam pembuatan beleidsregel, maka dapat disimpulkan bahwa Surat Edaran No. 511.2/DPP/PSR/IX/2018/200 yang dibuat oleh Dinas Perdagangan dan Perindustrian Kabupaten Siak, tidak ada masalah dalam pembuatan, baik dari segi muatan, kewenangan dan struktur surat.

\section{Penerapan Beleidsregel oleh Dinas Perdagangan dan Perindustrian dalam mengoptimalkan Pasar Rakyat Tualang di Kecamatan Tualang Kabupaten Siak Tahun 2018}

Tidak hanya dalam proses pembuatan, dalam proses penerapannya, beleidsregel juga memiliki beberapa persyaratan yang perlu diperhatikan oleh seluruh pihak yang terlibat dalam penerapannya. Menurut Ridwan HR hal yang perlu diperhatikan dalam penerapan peraturan adalah : 1) Sesuai dan serasi dengan tujuan undang-undang yang memberikan beoordelingsvrijheid (ruang kebebasan bertindak); 2) serasi dengan asas-asas hukum umum yang berlaku ( a. Asas perlakukan yang sama menurut hukum; b) Asas kepatutan dan kewajaran; c) Asas keseimbangan; d) Asas pemenuhan kebutuhan dan harapan; dan e) Asas kelayakan mempertimbangkan segala sesuatu yang relevan dengan kepentingan publik dan warga masyarakat); 3) Serasi dan tepat guna dengan tujuan yang hendak dicapai(Nasarudin, 2016). Berdasarkan tiga persyaratan penegakan beleidsregel menurut Ridwan HR, Surat Edaran No. 511.2/DPP/PSR/IX/2018/200 belum sepenuhnya memenuhi persyaratan tersebut. Berikut tabel penilaian Surat Edaran No. 511.2/DPP/PSR/IX/2018/200 :

Tabel 4. Penilaian Surat Edaran No. 511.2/DPP/PSR/IX/2018/20o berdasarkan persyaratan penegakannya.

\begin{tabular}{|c|c|c|}
\hline No. & Persyaratan dalam Penegakan Beleidsregel & Keterangan \\
\hline 1. & $\begin{array}{l}\text { Sesuai dan serasi dengan tujuan undang-undang yang } \\
\text { memberikan beoordelingsvrijheid (ruang kebebasan bertindak) }\end{array}$ & Sudah sesuai dan serasi \\
\hline 2. & $\begin{array}{l}\text { serasi dengan asas-asas hukum umum yang berlaku } \\
\text { a. Asas perlakukan yang sama menurut hokum }\end{array}$ & Sudah sesuai \\
\hline & b. Asas kepatuhan dan kewajaran & $\begin{array}{l}\text { Asas kepatuhan belum sesuai } \\
\text { dan asas kewajaran sudah sesuai }\end{array}$ \\
\hline & c. Asas kes€ & Sudah sesuai \\
\hline & d. Asas pemenuhan kebutuhan dan har & Sudah sesuai \\
\hline & $\begin{array}{l}\text { e. Asas kelayakan mempertimbangkan segala sesuatu yang } \\
\text { relevan dengan kepentingan publik dan warga masyarakat }\end{array}$ & Belum sesuai \\
\hline 3. & Serasi dan tepat guna dengan tujuan yang hendak dicapai & Belum sesuai \\
\hline
\end{tabular}

Sumber : Hasil wawancara dengan para Informan dan Olahan Penulis, 2019

Berdasarkan analisis di atas, maka menurut peneliti, penerapan Surat Edaran No. 511.2/DPP/PSR/IX/2018/200 belum sepenuhnya terlaksana dengan baik sehingga evaluasi

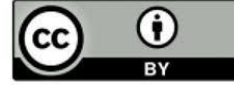


perlu dilakukan oleh Dinas Perdagangan dan Perindustrian agar dapat diketahui penyebab permasalahan sehingga dapat diselesaikan dengan tepat.

\section{Hambatan dalam Menerapkan Beleidsregel}

Dalam penggunaannya, surat edaran yang dikeluarkan oleh Dinas Perdagangan dan Perindustrian Kabupaten Siak tidak terlepas dari hambatan yang menyertainya. Tidak dipatuhinya surat edaran oleh pedagang kaki lima tersebut menjadi tantangan tersendiri bagi penegak hukum. Penegakan hukum aturan perundangan termasuk beleidsregels menurut Soerjono Soekanto sebagaimana dikutip Ilmar, terdapat lima faktor yang mempengaruhi penegakan hukum, yaitu [10] : 1) Faktor hukum itu sendiri; 2) Faktor penegak hukum; 3) Faktor sarana dan fasilitas yang mendukung penegak hukum; 4) Faktor masyarakat (lingkungan dimana hukum berlaku atau diterapkan); 5) Faktor kebudayaan sebagai hasil karya, cipta, dan rasa yang didasarkan pada karsa manusia di dalam pergaulan hidup(Adlin \& Yusri, 2020). Berdasarkan pendapat Soekanto, berikut tabel penilaian faktor-faktor yang menjadi penghambat penegakan beleidsregel :

Tabel 5. Faktor penghambat penegakan Surat Edaran No. 511.2/DPP/PSR/IX/2018/200

\begin{tabular}{|c|c|c|}
\hline No. & Faktor penghambat & Keterangan \\
\hline 1. & Faktor Hukum & Tidak \\
\hline \multirow[t]{3}{*}{2.} & Faktor Penegak Hukum & Semua sektor kurang serius dan tidak kooperatif \\
\hline & & PPNS Bidang Pengelolaan Pasar Tidak ada \\
\hline & & PPNS Satpol PP Kabupaten Siak tidak dilibatkan \\
\hline \multirow[t]{2}{*}{3.} & Sarana & Tidak adanya dukungan anggaran \\
\hline & Fasilitas & Terbatasnya jumlah personil penegak beleidsregel \\
\hline \multirow[t]{3}{*}{4 . } & Faktor Masyarakat & Karakter masyarakat (PKL) yang beragam \\
\hline & & Tingkat kesadaran hukum masyaraka rendah \\
\hline & & $\begin{array}{l}\text { PKL menilai Pasar Rakyat Tualang sudah bagus, tetapi kurang besar } \\
\text { dan strategis }\end{array}$ \\
\hline \multirow[t]{3}{*}{5 . } & Faktor Kebudayaan & Kebiasaan berjualan di pinggir jalan \\
\hline & & Budaya ingin praktis dari pembeli \\
\hline & & Budaya mewakili aspirasi konstituen oleh pejabat \\
\hline
\end{tabular}

Sumber : Hasil wawancara dengan para Informan dan Olahan Penulis, 2019

Berdasarkan paparan di atas, bertolak dari lima faktor yang mempengaruhi penegakan hukum dapat disimpulkan bahwa faktor-faktor yang yang menjadi penghambat dalam penegakan Surat Edaran No. 511.2/DPP/PSR/IX/2018/200 adalah yakni faktor penegak hukum, faktor sarana dan fasilitas, faktor masyarakat dan faktor kebudayaan. Beberapa fenomena menunjukkan bahwa sebuah surat edaran bahkan tidak dapat di implementasikan sama sekali ( non execute)(Rosaliana, 2018). Adajuga surat edaran yang pelaksanaannya tidak efektif karena tidak ditaati masyarakat(Prang, 2012). Tidak diataatinya surat edaran yang dikeluarkan pemerintah berhubungan dengan ketidaksiapan masyarakat menghadapi perubahan yang terjadi sebagaimana diamanatkan dalam surat edaran tersebut(Putri et al., 2020);(Rahman et al., 2019). Selain itu surat edaran yang sifatnya membatasi kebebasan atau aktivitas, seringkali tidak dipatuhi masyarakat(Astari, 2021). Sikap penentangan sebagaian masyarakat menunjukkan ketidakpatuhan mereka kepada pimpinan pemerintah daerah atau dinas yang berwenang(Sirajuddin, 2020).

\section{SIMPULAN}

Surat Edaran No. 511.2/DPP/PSR/IX/2018/200 tersebut sudah memenuhi persyaratan yang harus dipenuhi dalam pembuatan beleidsregels. Dari segi penerapan atau penegakan beleidsregel, Surat Edaran No. 511.2/DPP/PSR/IX/2018/200 yang dibuat oleh Dinas Perdagangan dan Perindustrian Kabupaten Siak belum sepenuhnya dapat diterapkan dan ditegakan dengan optimal. Hal tersebut karena ada beberapa persyaratan dalam penerapan atau penegakan beleidsregel yang sudah terpenuhi dan ada pula belum terpenuhi. Terdapat empat faktor yang menghambat penegakan dan penerapan Surat Edaran No. 511.2/DPP/PSR/IX/2018/200 yang 
dibuat oleh Dinas Perdagangan dan Perindustrian Kabupaten Siak yaitu faktor penegak hukum, faktor sarana dan fasilitas, faktor masyarakat dan faktor kebudayaan. Adapun faktor hukum tidak menjadi penghambat dalam penegakan atau penerapan surat edaran tersebut.

Kelebihan dari penelitian ini terletak pada sudut pandang yang digunakan yakni sudut pandang hukum tata pemerintahan sehingga dapat diketahui tindakan hukum pemerintah dalam mengoptimalkan Pasar Rakyat Tualang. Selain itu, informan dalam penelitian ini juga memiliki latar belakang dan keilmuan yang sesuai dengan bidangnya masing-masing. Kekurangan dari penelitian ini terletak pada masih sempitnya cakupan masalah yang hanya terbatas di wilayah administratif Kecamatan Tualang saja. Perkembangan ilmu pengetahuan selalu mengalami perkembangan. Oleh karena itu, peneliti tidak menutup kemungkinan untuk dilakukannya pengembangan penelitan lanjutan guna memperluas dan mempertajam khazanah ilmu pengetahuan dalam bidang sosial humaniora dan hukum terutama dalam kajian hukum tata pemerintahan.

\section{UCAPAN TERIMA KASIH}

Terimakasih penulis ucapkan kepada Jurusan Ilmu Pemerintahan FISIP Universitas Riau sebagai pihak yang telah bersedia mendanai penulisan artikel ilmiah ini. Selain itu, rasa terimakasih juga penulis ucapkan kepada Kepala Jurusan Ilmu Pemerintahan FISIP Universitas Riau serta seluruh dosen Jurusan Ilmu Pemerintahan FISIP Universitas Riau yang telah memberikan dukungan kepada penulis sehingga artikel ilmiah ini dapat terselesaikan sebagaimana mestinya.

\section{DAFTAR PUSTAKA}

Adlin, \& Siregar, J. F. (2021). Partisipasi Politik Mahasiswa Kota Pekanbaru Terkait Dukungan Presiden Dalam Pengesahan Revisi Undang Undang Komisi Pemberantasan Korupsi Tahun 2019. Reformasi, 11(1), 86-96. https://doi.org/10.33366/rfr.v

Adlin, A., \& Yusri, A. (2020). Penegakan Hukum Pemerintahan: Kekuasaan Walikota Pekanbaru Memberlakukan Beleidsregels Guna Memutus Penyebaran Virus Covid- 19 Di Kota Pekanbaru. Jurnal Ilmiah Muqoddimah: Jurnal Ilmu Sosial, Politik Dan Hummaniora 4(2), 71. https://doi.org/10.31604/jim.v4i2.2020.71-81

Anam, M. C., \& Hafiz, M. (2015). Surat Edaran Kapolri Tentang Penanganan Ujaran Kebencian (Hate Speech) dalam Kerangka Hak Asasi Manusia. Jurnal Keamanan Nasional, 1(3), 341-364. https://doi.org/10.31599/jkn.v1i3.30

Astari, A. (2021). Politik Hukum Pelarangan Demonstrasi Mahasiswa melalui Surat Edaran Kemendikbud No. 1035/E/KM/2020 Di Masa Pandemi. Jurnal Hukum UNISSULA, 37(1), 24.

Badan Pusat Statistik kabupaten Siak. (2019). kecamatan Tualang dalam AngkaTahun 2018. Badan Pusat Statistik Kabupaten Siak.

Bungin, B. (2013). Metodologi Penelitian Sosial dan Ekonomi. Prenadamedia Group.

Eric, \& Anggraita, W. (2021). Perlindungan Hukum Atas Dikeluarkannya Peraturan Kebijakan ( beleidsregels). Jurnal Komunikasi Hukum, 7, 387-402.

Ifaundra, M. (2016). Relokasi pasar Puakang Ke pasar Maimun di kabupaten Karimun Tahun 2012-2013. Universitas Riau.

Ilmar, A. (2014). Hukum Tata Pemerintahan. Prenadamedia Group.

Ismahyuni, A. (2018). Kedudukan Ancaman Pidana Minimal Dalam Undang Undang Nomor 35 Tahun 2009 Tentang Narkotika Pasca Dikeluarkan Surat Edaran Mahkamah Agung Nomor 3 Tahun 2015. Jurnal Panorama Hukum Jurnal Panorama Hukum, 3(1), 19-32.

Nasarudin, T. M. (2016). Pembuatan Instrumen Pemerintahan. Jurnal Hukum Novelty, 7(2), 139-154.

Prang, A. J. (2012). Eksistensi dan Efektivitas Surat Edaran Larangan Kangkang. Media Syariah, XIV, 213224.

Putri, W. D., Fakhruddin, F., \& Wanto, D. (2020). Persepsi Orang Tua Terhadap Surat Edaran Kemendikbud Tentang Belajar Dari Rumah Dimasa Pandemic Covid 19. At-Ta'dib: Jurnal Ilmiah Prodi Pendidikan Agama Islam, 12(2), 97-111. https://doi.org/10.47498/tadib.v12i02.364

Rahman, R. N., Ispriyarso, B., \& Adiyanta, F. C. S. (2019). Penerapan Parkir Elektronik ( E-Parking) di Kota Surakarta Sebagai Implementasi Surat Edaran Menteri Dalam Negeri Nomor 910/1867/SJ Tentang 
Wulan Dari \& Adlin. Beleidsregel Dinas Perdagangan dan Perindustrian dalam Mengoptimalkan Pasar Rakyat Tualang Tahun 2018

Implementasi Transaksi Non Tunai Pada Pemerintah Daerah Kabupaten/Kota. Diponegoro Law Journal, 8(4), 2706-2718.

Ridwan. (2007). Hukum Administrasi Negara. PT. Raja Grafindo Persada.

Rosaliana, M. (2018). Implementasi Surat Edaran Mahkamah Agung Nomor 7 Tahun 2001 Tentang Pemeriksaan Setempat Dalam Menyelesaikan Sengketa Tanah Pada Pengadilan Negeri Stabat. Doktrina : Journal of Law, 1(2), 104-124.

Sebastian, E. van. (2018). Upaya Penataan pasar Pajak lama oleh pemerintah daerah kabupaten Rokan Hilir tahun 2017. Universitas Riau.

Sirajuddin. (2020). Peniadaan Salat Jumat Dalam Surat Edaran Gubernur Sulsel Nomor : 451.11/2057/2020 Selama Pandemi Covid-19 Persfektif Maqasid Al-Syariah. Jurnal Nukhbatul 'Ulum: Jurnal Bidang Kajian Islam, 6(2), 289-309.

Syaukani, Gaffar, A., \& Rasyid, R. (2009). Otonomi daerah dalam Negara Kesatuan. Pustaka Pelajar.

Undang Undang Republik Indonesia. (1999). Undang Undang Republik Indonesia Nomor 22Tahun 1999 Tentang Pemerintahan Daerah.

Undang Undang Republik Indonesia. (2004). Undang Undang Republik Indonesia Nomor 32 Tahun 2004 Tentang Pemerintahan Daerah.

Undang Undang Republik Indonesia. (2014a). Undang Undang Republik Indonesia Nomor 23 Tahun 2014 Tentang Pemerintah Daerah.

Undang Undang Republik Indonesia. (2014b). Undang Undang Republik Indonesia Nomor 7 Tahun 2014 Tentang Perdagangan.

Yuliansyah, F. (2015). Kajian Hukum terhadap terbitnya Surat edaran Kapolri Nomor: 06/X/2015 Tentang Penanganan Ujaran Kebencian (hate Speech) (Vol. 151, Issue 06) [Muhammadiyah Jember]. https://doi.org/10.1145/3132847.3132886 